\title{
AN EXAMPLE OF MEANINGLESS LEGITIMIZATION TRADITION IN ANCIENT MEDITERRANEAN REGION: EXPOSE TO WATER
}

\author{
Murat TURGUT* \\ Yeşim DILEK ${ }^{* *}$
}

\author{
Makale Bilgisi \\ Başvuru: 13 Nisan 2021 \\ Kabul: 24 Mayıs 2021
}

\section{Article Info}

Received: April 13, 2021

Accepted: May 24, 2021

\begin{abstract}
Many ancient civilizations glorified their kings, divine beings and heroes. In order to make them unreachable, ancient societies first of all separated the lives of these personas into two parts and created a turning point for them, and especially the first part of their lives was detailed with extraordinary events to make them the main theme of some mythological stories. The plot of these stories generally was related to the theme of the abandonment of a new-born or sometimes an adult to water in any object like basket, crate or closed box, and eventually his reaching to a vital position for society.
\end{abstract}

* Assistant Professor Dr., Selcuk University, Faculty of Letters History, Ancient History Department, mturgut@selcuk.edu.tr, muratturgut09@gmail.com; ORCID: 0000-00031056-5737

** Lecturer Dr. Selcuk University, School of Foreign Languages English Department, yesimakan@selcuk.edu.tr: ORCID: 0000-0003-0863-5468 
The generally accepted view in the literature is that rulers, especially those who were not legitimately entitled, manipulated such mythological stories to legitimize their dominance in the public eye. Moreover, as far as it is concerned that divine characters and some heroes were legitimized in this way.

Contrary to the generally accepted judgment, it is confirmed that the majority of the abandoned children had already had opportunities to come to the fore. The mounted arguments of this study have mostly been based on the antique sources, and it is aimed to reveal the fact that the individuals who were left on water in arks had already been prospective legitimate people on the domains of administration or religion.

Keywords: Abandonment, Prospective Personas, Legitimacy, Administration, Deification.

\section{Antik Akdeniz Bölgesi'ndeki Gereksiz Meşrulaştırma Geleneğinin Örneği: Suya Terk Etme \\ $\ddot{O} \mathbf{z}$}

Eskiçağdaki birçok medeniyet krallarını, tanrısal varlıklarını ve kahramanlarını yüceltmişlerdir. Onların, ulaşılamaz bir konuma gelebilmesi için, özellikle yaşamlarının ilk bölümünü, olağanüstü olaylarla süsleyerek mitolojik hikâyelerinin konusu yapmışlardır. Genel olarak bu hikâyelerin konusu yeni doğan çocuğun veya bazen yetişkinlerin sepet, sandık veya bir kutu içerisinde suya veya suyla ilişkili yerlere terk edilmeleri ve sonunda da toplum için çok önemli bir konuma ulaşmaları ile ilişkili olmuştur.

Genel olarak kabul edilen görüş meşru olarak yönetme yetkisi olmayan yöneticilerin halkın gözündeki üstün konumlarını meşrulaştırmak için bu tür mitolojik hikâyeleri kullanmaları olmuştur. Tanrısal varlıklar ve kahramanların da bu yolla meşrulaştırıldıkları da düşünülmüştür.

Literatürde genel olarak kabul edilen düşüncenin aksine suya terk edilmiş çocukların zaten ön plana çıkması güçlü ihtimal olan çocuklar olduğu görülmüştür. Bu çalışmada çeşitli sebeplerden dolayı su veya suyla ilişkili yerlere terk edilen çocukların büyük çoğunluğunun zaten meşru kişiler oldukları antikçağ yazarlarının verdikleri bilgiler ışığında ortaya çıkarılması amaçlanmıştır.

Anahtar Kelimeler: Bırakma, Kutsanmış kişiler, Meşrulaştırma, Yasallaştırma, Yönetim, İlahlaştırma. 


\section{Introduction}

Many of the ancient societies glorified their religious people, kings and heroes. ${ }^{1}$ These communities made the occurrence and existence and of these substantial people the subject of their mythological stories by embellishing especially the beginning of their lives with supernatural and extraordinary events to transmit their position into an inaccessibility. The theme of these stories was generally related with their abandonment when they were just a new-born baby and their amazing survival.

The abandonment of babies was not only encountered in legends and stories; it is also known that new-born babies were abandoned in real life in the ancient world. Especially in the period of ancient Greek and Roman, it seems that poor families abandoned their girls and when appropriate they even left their boys. The possible physical or mental deficiency and disability of the new-born, the poverty of the family, the illegitimacy of the child, the bad signs coming from gods and except poorness, family's inadequacy to raise the child may have been the reasons for the families to abandon their children. ${ }^{2}$

Children who were abandoned in real life were not as lucky as the children that were seen in mythological stories. It is made firm that, many of the children who were abandoned in real life for various reasons were killed or they die in the end, ${ }^{3}$ and a small number of girls, who were lucky, were raised by adopted families under normal conditions; the unlucky ones were brought up for prostitution. ${ }^{4}$

Although the lives of these kind of children generally would have an undesirable future, the ones who were sharing the same destiny in mythological stories had a promising future. It is recognized that these children turned into the characters who would lead the society as rulers, heroes or influential religious people. These individuals either made themselves the leading actor of a mythological legend or were brought to this position by the

1 Irene J. Winter, "Touched by the Gods: Visual Evidence fort he Divine Status of Rulers in the Ancient Near East", Religion and Power Divine Kingship in the Ancient World and Beyond, ed. Nicole Brisch, (Chicago: The Orieantal Institute, 2008), 75.

2 W. V. Harris, "Child-Exposure in the Roman Empire", The Journal of Roman Studies 84, (1994): 11, 12; Pierre Brulé, "L'exposition Des Enfants En Grèce Antique: Une Form D'infanticide", Enfances \& Psy. 3, (2009): 19 - 23. Also Hatice Palaz Erdemir and Halil Erdemir, "Antikçağ'da Çocuk Olmak: Ölmek ya da Ölmemek", The Symposium of Violence against Women and Children Proceedings Book, (2012): 649, 650.

3 La Rue van Hook, "The Exposure of Infants at Athens", Transactions and Proceedings of the American Philological Association 51, (1920): 136; Marlies Konijnenberg, Infanticide and the Social Status of Children As Reflected in Child Burials, Unpublished BA Thesis, (2014): 2.

4 Harris, "Child-Exposure," 10. 
society. In any case, the result is that they were no longer regarded as ordinary human beings but perceived as superhuman beings.

The reasons of individuals being the main theme and protagonist of these type of mythological stories are not clarified exactly. Nevertheless, generally accepted idea about this fact is that the ones, who did not deserve their statues, used this method in order to legitimize their own situation. However, there are other opinions supporting that these people took part in those stories so as to emphasize and claim that they were real superhuman beings and coming from mythical times. ${ }^{5}$

Although perhaps people witnessed so many times that most of the children, who were abandoned, died in real world, still they believed that they could survive extraordinarily in various ways in mythological legends. Their attitude was also able to confirm the idea that ancient people accepted certain matters which were related to their religion perception without questioning or basing them upon logic. ${ }^{6}$ Thus, people were not concerned with the question of why and how these children could survive.

The dates of appearance of such myths are not completely known. As far as it can be learned from the written documents, it is thought that legends were products of the oral tradition, and that it might have been transferred into the text after the writing system began to be used. ${ }^{7}$ Therefore, it can be said that the origin of these myths could possibly go back to prehistoric times.

When some cultural features belonging to the ancient world are searched, it seems that similar elements existed even in cultures which located distant regions from each other. Where or in what way these similarities originated could not be determined accurately, but various opinions have been put forward about this issue. Frazer made a statement including three possibilities about this issue. According to his description, these facts may have been formed by direct contact of communities with each other, by means of intermediary communities, or by the figment of society's own imagination. ${ }^{8}$ Eliade emphasized that religions and beliefs were influenced by each other. ${ }^{9}$

5 Mircea Eliade, Mitlerin Özellikleri, Translate: Sema Rifat, (İstanbul: Om Yayınevi, 2001), 15, 16.; Also Giulia Pedrucci, "Breastfeeding Animals and Other Wild "Nurses" in Greek and Roman Mythology", Gerión 34, (2016): 316.

6 Lucien Lévy-Bruhl, Ilkel Toplumlarda Mistik Deneyim ve Simgeler, Translate: Oğuz Adanır, (İstanbul: Doğu Batı Yayınları, 2006), 91.

7 F. Carter Philips, "Greek Myths and the Uses of Myths". The Classical Journal, LXXIV/2, (1979): 157.

8 James George Frazer, Man, God and Immortality Thoughts on Human Progress. (London: Macmillen and Co, 1927), 48 - 50.

9 Mircea Eliade, Dinler Tarihine Giriş, Translate: Lale Arslan, (İstanbul: Kabalcı Yayınevi, 2003), 78, 79. 
Lévy-Bruhl stated that the feature of sanctity and some traditions were transferred to future periods both temporal and spatially. ${ }^{10}$ Redford on the other hand depended the reason of this similarity on the fact that myth makers and storytellers were inspired from common mythological stories which had been collected in documents and minds for centuries, and in his opinion, such myths were standardized by a culture or some cultures that managed to reach a high level in later periods. ${ }^{11}$

\section{Legendary Characters in Arks}

These similarities existing in many different civilizations' cultures included mythological stories making the lives of divine - religious beings, kings and heroes legendary, and elevating their survival to superhuman levels. Although there are some differences between these mythological stories, a general structure of this kind can be revealed. ${ }^{12}$ According to the widespread framework, negative signs had been prophesied to the father or the king before a child's birth who would become the hero/king/divine being in the future. Therewith, the one receiving the negative omens consulted the oracles and wanted them to interpret the signs, and as a result it was decided that the child had to be killed. In some legends, the child was put into a crate and left on water to be killed, and in others he was left to die by being released to nature. However, after a while, the child was found and raised by people or animals thanks to the help of the gods. When he grew up, either he got back at his first family, who somehow abandoned him, or he held on his new life to become a prospective divine being, a king, or a hero.

As can be seen in the general structure of this type of mythological legends, the new-born baby was either abandoned to nature or on water inside a basket, box or a crate. Our subject here concerns the stories of children who were left on water in any object. Because ancient people regarded water as the source of all existence, the premise of every form of creature namely whole nature, and every cosmic cycle containing beginnings and ends. ${ }^{13}$ It is also known that water was accepted as a source of life containing eternity, purification and life itself.

10 Lévy-Bruhl, "Mistik Deneyim," 162.

11 B. Donald Redford, "The Literary Motif of the Exposed Child (Cf. Ex. ii 1 - 10)". Numen XIV/3, (1967): 209.

12 Otto Rank, The Myth of the Birth of the Hero A Psychological Interpretation of Mythology, (New York: The Journal of Nervous and Mental Disease Publishing Company, 1914): 36; Sigmund Freud, Moses and Monotheism, Translated from the German By Katherine Jones, (Hertfordshire: Hogarth Press and the Institute of Psycho - Analysis, 1939): 16, 17.; Redford, "Exposed Child," 211.

13 Eliade, Dinler Tarihine, 196, 206. 
In ancient times people ascribed special meanings to leave a child on water just like they found different values in water itself. In fact, they thought of leaving the child on water meant the beginning of his rebirth and his new destiny thanks to the cosmic power water. ${ }^{14}$ The child who was left on water was thus a kind of preparation for the concept of birth, which would be the new start of a new life and destiny symbolically. Apart from enabling the beginning of a new destiny, the water was the symbol of purity and it had cleansing function ${ }^{15}$ so the child may have been left on the purpose of being purified. In this way the child who left on water in any object was able to begin his new life or destiny in a clean and purified manner.

In such mythological legends, the objects such as crates, boxes or baskets in which the child was put could have had certain symbolic meanings. These objects in which the child was abandoned to his fate might have been likened to a mother's womb. ${ }^{16}$ Thus the child could experience a symbolic birth for his new life. This was also associated with the initiation of the child. The prospective child was included in the most important and dangerous experience of his life by being abandoned in an ark on water and when he managed to survive, he was born again as having a different body, and it was thought that he had a completely different personality. ${ }^{17}$

The general structure of these kinds of mythological stories should also be examined in terms of their religious meanings. The child who was born as a normal person needed a new beginning in order to change his destiny and become a completely different person. This could only be possible symbolically by means of rebirth. Accordingly, the child was placed into a basket/box/crate representing the mother's womb for the rebirth. The child did not die and managed to survive thanks to the support and wishes of the gods. Due to its contact with water, he was also cleansed and purified religiously. Then the new destiny of the child began by being found and rescued someone, so a sort of birth came true.

The legends of abandonment any individual in any container on water generally related to the children in ancient times of Mediterranean

14 Rank, The Myth of, 69 - 71.; Eliade, Dinler Tarihine, 252.

15 James George Frazer, The Golden Bough I, A Study Comparative Religion. (New York and London: Macmillan and Co, 1894): 208, 297, 298.; James George Frazer, The Golden Bough II, A Study Comparative Religion. (New York and London: Macmillan and Co, 1894): 52, $53,192$.

16 Rank, The Myth of, 70.; Freud, Moses and Monotheism, 18.; Frazer, The Golden Bough I, 279.; Mircea Eliade, Rites and Symbols of Initation the Mysteries of Birth and Rebirth, (New York: Harper Colophon Books, 1958), 51.; Mircea Eliade, Demirciler ve Simyacilar. Translate: Mehmet Emin Özcan, (İstanbul: Kabalcı Yayınevi, 2003), 43.

17 Eliade, Rites and Symbols, x, xiv. 
Civilizations. However, it seems that apart from children, some of the adult prospective personas also reached their vital positions for their societies as they had to have a contact with water in any way. It is accurate that in some of these significant stories protagonists had already been important religious man before the events. Nevertheless, as it is understood from the legends that their life would not be the same when they had a connection with water. According to the stories, these adult individuals somehow had exposed to water in their life process as a sign of significant point, but consequently their lifes did not completely changed as generally accepted. Whatever they had been in their first life (generally county family / religious official) it is known that at the end of the story their destiny was shaped so they could be in an appreciable status for their societies.

\section{Stories of Prospective Personages}

In the ancient world, a large number of mythological myths containing the theme of abandonment of a new-born baby to nature or water to die, his survival and future experience with a new destiny was handled. An important part of these myths constituted the subject of abandonment on water.

As learned from the written sources, the oldest version of the legends including the subject mentioned above was known as the legend of Sargon who was the king of Akkad. In the following translation of the legend, Sargon's birth, his life, and his becoming king with the help of his goddess Ištar are mentioned. ${ }^{18}$

"Sargon, the mighty king, king of Agade, am I.

My mother was a nun, my father I knew not.

The brother(s) of my father loved the hills.

My city is Azupiranu, which is situated on the banks of the Euphrates.

My changeling mother conceived me, in secret she bore me.

She set me in a basket of rushes, with bitumen she sealed My lid.

She cast me into the river which rose not (over) me,

The river bore me up and carried me to Akki, the drawer of water.

Akki, the drawer of water lifted me out as he dipped his e[w]er.

Akki, the drawer of water, [took me] as his son (and) reared me.

Akki, the drawer of water, appointed me as his gardener,

18 E. A. Speiser, "Akkadian Myths and Epics from Mesopotamia”, The Ancient Near East I An Anthology Of Texts And Pictures. ed. J. B. Pritchard (Princeton: Princeton University Press, 1958), 85-86.; Joan Goodnick Westenholz, Legends of the Kings of Akkade: The Texts, (Pennsylvania: Eisenbrauns Publications, 1997), 39-41. 
While I was a gardener, Ishtar granted me (her) love, And for four and [...] years I exercised kingship..."

The text gives details about the birth of Sargon, King of Akkad, and his life after his birth in Mesopotamia. When it is examined within a general framework, it is seen that his mother had religious duties in the temple. Why Sargon had been abandoned in a basket to the Euphrates River by his mother was not mentioned in the text. However, the fact that being her mother a priestess may have indicated that she left her child because of a secret or forbidden relationship that she had. Sargon was found and raised by a watercarrying man who was a poor man from lower class in the city of Akki. With the passing years, as he stated himself, he became the king of Akkad thanks to the help of his goddess Ištar.

\section{Moses}

The king of Egypt sought advice of his oracles about a dream he had, and this dream was interpreted as the king's reign would be endangered by a child to be born. Thereupon the king ordered that all the new-born babies to be killed. According to the Old Testament, the incident continued as follows: ${ }^{19}$

"After this there went a man of the house of Levi; and took a wife of his own kindred. And she conceived, and bore a son: and seeing him a goodly child, hid him three months. And when she could hide him no longer, she took a basket made of bulrushes, and daubed it with slime and pitch: and put the little babe therein, and laid him in the sedges by the river's brink, His sister standing afar off, and taking notice what would be done. And behold the daughter of Pharao came down to wash herself in the river: and her maids walked by the river's brink. And when she saw the basket in the sedges she sent one of her maids for it: and when it was brought, She opened it, and seeing within it an infant crying, having compassion on it, she said: This is one of the babes of the Hebrews. And the child's sister said to her: Shall I go, and call to thee a Hebrew woman, to nurse the babe? She answered: Go. The maid went and called her mother. And Pharao's daughter said to her: Take this child, and nurse him for me: I will give thee thy wages. The woman took and nursed the child: and when he was grown up, she delivered him to Pharao's daughter. And she adopted him for a son, and called him Moses, saying: Because I took him out of the water."

19 Exodus 2: 1- 10. 
In the sequel, Moses lived in the king's palace and became a religious character. In addition, the knowledge which was mentioned in the Old Testament that the name Moses meaning "coming out of water" was given to him. However since he was removed from the water is not accurate, it is stated that Moses may refer to other meanings. ${ }^{20}$

As it is clear in the story of Moses, he had been the child of a poor and lower class family. Due to a prophetic warning the king received, he was left by his mother on the River Nile to save him from the decision about the general baby massacre that the king made. Then by chance he was found and rescued by the daughter of the king of Egypt who went to the riverbank, and was taken to the palace and raised there. Thereafter Moses became one of the most important religious characters in the world history.

\section{Darab}

In the main theme of Shahnameh which is known as one of the most important literary works of Iranian literature, an abandoned child and his being raised by others and becoming king was described. According to the legend, ${ }^{21}$ after Bahman's death, Húmaí became the ruler of the state.

She was pregnant and when the moment of birth came she gave birth to her son secretly. Because she loved the power of the throne and wanted her reign to go on, she concealed the child and told the inquirers that the child was dead. Eight months after the birth of the child, she ordered her carpenters to make a sturdy basket and she made it waterproof. In the middle of the night, she threw this ark containing the baby into the Euphrates. When it was morning, the washer men noticed the basket and the child inside. One of the washer man removed the child from the basket and took him home to raise him with his wife, and they named the boy Darab.

As the child grew, he became as strong and beautiful as a god. He later learned about his past from the mother who raised him. When he grew up Darab joined the army, and during one military expedition, suddenly a strong storm broke out and he hardly found a place of refuge. Then someone in the army saw him and realized that he was carrying divine signs. Darab was given a good horse and a gold-plated sword, and he won through in the battle of that day and the other battles.

In the following of the legend, Húmaí encountered his son Darab and told him what had happened and how she had left him on the river. Then,

20 Freud, Moses and Monotheism, 12, 13.

21 Shahnameh $294-312$. 
Humai left the crown and the throne to his son Darab, and he became the king and also took care of the family who raised him.

According to the general framework of this legend, Darab's first family had been a royal family. Due to his mother's ambition for throne, sometime after his birth he was abandoned to the Euphrates in a basket. Darab's second family was poor, and he was raised by this family. Consequently, Darab first became a good warrior and then a king.

\section{Karna}

The subject of Mahabharata which has been one of the most important epics of Indians is again about the life, experiences, survival and becoming the king of a child who was abandoned to water in a basket. ${ }^{22}$

According to the story, Kunti was tricked by the god of sun Surya with various promises, and had a sexual intercourse with the sun god. Karna whose life had been guaranteed by this god was born from this relationship. As soon as Kunti gave birth to the child, she consulted her babysitter and had her prepare a waterproof basket. She put the boy into the basket with expensive pillows and some other materials and left it on the Aswa River. ${ }^{23}$ The basket proceeded through the Aswa, and eventually reached the Ganges River.

On the Ganges River, the charioteer's wife saw the basket. He took the basket out of the Ganges and opened it. After seeing the child's beauty, they thought the gods had given it to them as a gift. They adopted and took care of him. In the later years, Karna managed to be the king of the Anga after taking part in numerous battles and duels.

The general concept of the story of Karna demonstrates that his first family had been a wealthy family, and he was born as a result of a sexual relationship with god. As seen in the stories above, Karna was abandoned by her mother to the Aswa River which is a tributary of the Ganges River. The child's second family was a poor family. Being raised by this poor family, he could become both a legendary warrior and a king in the future.

\section{Telephos}

Although various versions were written out by antique writers, the common point of all is that Telephos was one of the children who was abandoned on water. The legend has it that, Auge whose father was Aleus, the

22 Mahabharata, III, 305: 594 - 599; I, 138: 288, 289. This part of myth was associated with both birth of Christ and Mose's expose to water in basket. Moritz Winternitz, Hint Destanları Rāmāyana, Mahābhārata, Harivamşa, Translate: Korhan Kaya, (Ankara: İmge Kitabevi, 2016): 72, 73.

23 In some parts of the legend it was mentioned that the child was left on directly on the Ganges River instead of the Aswa River. 
king of Tegea became pregnant to Telephos as a result of sexual relationship with Heracles. With the help of divine signs augured him before, Aleus learned that this child would pose danger to his reign. Although Auge tried to persuade his father about the important divine position of the child's father, Aleus did not believe her. The woman had to give birth to her child secretly. However Aleus got the picture, so he put her daughter and Telephos in a crate, and left them on the sea. When the ark came to the shores of Mysia, the king of the region named Teuhtras rescued them. He made Auge his wife and Telephos his own son. ${ }^{24}$

Although there are some contradictions in the narrations of antique writers in terms of the events especially after Telephos had been abandoned, the general motif of the legend was based on the fact that Auge did not die, and that her and her son's life were somehow united with the king of Mysia. Telephos anywise reached to Mysia and Teuthras accepted him as his own son or he got married with Teuthras' daughter. Regardless of how it happened in the end he became the king of Mysia

In the story of Telephos, which started in Greece and continued in Anatolia, it is apparent that his first family had been a wealthy royal family. Because the king did not believe his daughter's sexual relationship with a god, he put his daughter and her son into a crate and left it on the sea. The second family of Telephos was also a royal family, and in the end Telephos became the king.

\section{Perseus}

One of the most important heroes of the mythological stories in the ancient world was Perseus. He also became legendary with the help of a story telling the abandonment on water in a basket. Legend had it that the king Acrisius of Argos wanted to conduct a prophetic investigation to learn how to be able to have a boy. Divinations indicated that his sister's male-child would kill the king and become the ruler of Argos. So Acrisius built a chamber made of brass underground and tried to keep his sister Danae away from people by imprisoning her there. According to some resources, it was Proteus, but as to

24 Strabon XII. 1.69. In works of other writers, the child was left in different places. According to Pausanias, Aleus wanted his daughter Auge to be drowned at sea, and he commissioned one of his men, Nauplis, to do so. However, Auge was able to escape. Pausanias stated that there was a different version of the story. In this narrative, Auge gave birth to Telephos without notice to her father and was immediately abandoned him on the Mountain of Parthenius. Pausanias VII. 48.7. The narration of Diodorus of Sicily is also similar to the other narration of Pausanias. Diodorus wrote that Auge was given to Nauplis to be drowned at sea, that Auge somehow led Nauplis to Mount Parthenius where she gave birth to Telephos and abandoned him there. Diodorus, IV. 33. 7 - 12. There are also two narratives of the legend in Apollodorus' work. In these narratives the child was abandoned to Mount Parthenius under different circumstances. 
some others, it was Zeus as a form of rain of gold infiltrated in the place where Danae was trapped and had a sexual relationship with her. Danae gave birth to a boy from this relationship, but his older brother did not believe what his sister said, and he put his sister in a crate with Perseus and throw the ark into the sea. ${ }^{25}$

In the other part of the legend, it is seen that the ark was washed up onto the shores of Seriphus. Dictys, who was the king of the city of Seriphus, found them and took care of the child. Prospective king of Seriphus, Dictys' brother Polydectes fell in love with Danae. The rescue of Perseus Andromeda played an important role among the mythological stories such as the legend of Medusa. At the end of the legend, the prophecy of Acrisius came true, and even if it was by mistake Perseus became the king of Argos by killing Acrisius. ${ }^{26}$

In the general theme of the legend of Perseus, it is again seen that the first family was royal. As a result of a secret relationship with God, Perseus came into the world and he and his mother were put into a crate and left on the sea by the king. Perseus' second family was also a royal family similar to Telephone's. When Perseus grew up, he became one of the most important heroes of the ancient Greek mythology being as the son of Zeus and also king of Argos.

\section{Romulus and Remus}

One of the states that deeply affected world history and civilization was Rome. According to the so-called legend of the founding of Rome, the children who were abandoned played the most important role on the founding of this city managed to survive spectacularly.

As we learn from the antique writers that idea of establishment of the Roman city first appeared by the decisions of the gods of destiny. The first attempt to make the decision come true was being kidnapped of the priestess of Vesta and probably she was impregnated by Mars. Despite the fact that she had intercourse with a god, she could not escape the king's cruelty. While her children were left in a basket on the Tiber River to die, she was concatenated and imprisoned by the king. Those who left the basket thought that the children were going to die, but fate went in their favour and they survived accomplishedly. As the river got shallower, the basket approached the shore and a she-wolf came to the basket and suckled the children. The king's shepherd named Faustulus found these children lying and being cleaned by the wolf. The shepherd took them home and raised them with his wife. ${ }^{27}$ In

25 Apollodorus, II. 4.1.

26 Apollod., II. 4. 1-4.

27 Livius, I. 4. With some minor changes, the legend was similarly described in Plutarch. As Plutarch stated that Amulius who was the king of Alba, learned that if his brother Numitor's daughter had given a birth to a boy, the child would have been a danger for him. He decided to 
the following of the legend those two brothers founded the city of Rome. However then because of a trivial reason Romulus killed his brother Remus.

In general framework of the story's theme, it is apparent that the first family of the children abandoned on the Tiber River belonged to royalty. They were left because of the secret relationship that their mother had with a god. At first a she-wolf found them and then a lower class shepherd family raised them. At the end of the legend Romulus became the first king of Rome.

\section{Fabius Maximus}

Fabius Maximus, who was one of the important politicians of the Roman Empire, was also among those whose life has been made legendary. According to the legend told by Plutarch, Fabius was born out of a native woman's relationship with Hercules. After his birth, he was abandoned on the edge of the Tiber River. In the forthcoming days of his life, this child grew up with his mother and became the founder of the Fabii family. ${ }^{28}$ In addition, Fabius gained considerable success in the Roman army and took also part in the consulship and dictatorial authorities of Rome.

The legend of Fabius Maximus outlines that on the contrary to other stories told of above, the child's first family did not belong to royalty or they were not rich. It is known that he was born as a result of a relationship with a god. However, the status of his second family or by whom he was raised was not mentioned. At the end of the legend, we learn that Fabius became one of Rome's most famous rulers.

\section{Pyrrhus}

Pyrrhus was the famous Greek general of the Hellenistic period and became the king of Epirus. The first period of his life was also made legendary, and was associated with the river or water indirectly. According to the legend told by Plutarch, the king Aeacides of Molossians, got married with Phthia from Thessalia, and one of the children born as a result of this marriage was Pyrrhus. During the fight between the Molossians, Aeacides were expelled from the city and the vast majority of their men were killed. The enemies of Aeacides chased after Pyrrhus who was only a small infant. However, Androcleides and Angelus kidnapped Pyrrhus and prevented him from being killed. Looking for a place to escape from their enemies, they came

make her a priestess in Vesta temple so that she couldn't have an affair with anyone. A short time later, the girl fell pregnant non-compliantly in the temple of Vesta. Thereupon, nothing was done until the birth of the children, and after their birth the women were punished to weave for a large number of people and the children were left to die in the Tiber River. The children were saved from dying with the help of the gods and fed by the she-wolf. Then a shepherd saw the children took them home and raised them. Plutarch Romulus, III, IV.

28 Plutarch Fabius, I. 
near a fast-flowing river bank. They couldn't cross the river during the day, and when it got dark in the evening and as rain started, the situation got worse. They could not made themselves heard to the people on the other side of the river that they had to cross the river. Then one of them wrote a message saying that they needed them and managed to throw it across the river. When those on the other side of the river read the message, they immediately brought a boat. Putting also Pyrrhus in the boat, they saved them. Escaping from the enemies, these people went to the king of Illyria, Glaucias to ask for help. When they reached the King's presence, Pyrrhus crawled towards the altar and turned around it. The king interpreted this act as a sign of god and taking the child and he raised him himself. ${ }^{29}$

Being raised by Glaucias, Pyrrhus greatly improved himself in the military and political spheres. Then, he became the king of Epirus, and he defeated Rome although he lost a great number of soldiers in the battlefield. Moreover the English term "pyrrhic victory" has been used to tell such a kind of victory in English dictionaries today. ${ }^{30}$

The abilities that Pyrrhus had were not only restricted in the fields of military and politics. Plutarch, who gave information about life of Pyrrhus also mentioned some rumors that the right thumb of Pyrrhus had godlike features and fire could not harm his body. ${ }^{31}$

In the outlines of the legend of Pyrrhus, it is stated that the first family that child was born was the King's family. When he was a baby, he had to cross the river with his father and his fellows to escape from the enemies and was raised by his father's men. After then the king of Illyria was adopted him, and therefore his second family was also a wealthy royal family. In the forthcoming years, he served as the ruler of Eiprus and gained successful victories against Rome.

\section{The Children of the Queen of Kaniš}

Children who were left in the basket were often alone or with their mother. According to a mythological legend in Anatolia, ${ }^{32}$ it is estimated that more than one child was left on the river at the same time. However, we cannot learn the certain result because of the tablets have been damaged.

According to the legend of the Queen of Kaniš, or also known as the legend of Zalpa, the woman named as the queen of Kaniš gave birth to thirty

29 Plutarch Pyrrhus, $1.4-3.3$.

30 It means a victory in which the person who wins suffers so much that the victory was hardly worth winning. Longman Dictionary of Contemporary English.

31 Plut. Pyrr., 3.5.

32 Heinrich Otten, Eine Althethitische Erzählung um die Stadt Zalpa, (Otto Harrassowitz Wiesbaden: Studien zu den Boğazköy - Texten, 1973), 7. for KBo XXII. 2. 1 - 20. 
boys in one go. Considering she had actualized an extraordinary and unusual thing, he had a basket prepared and left the children on the river in it. The river took them to the shore of Zalpa and the children were taken and raised there by the gods. After many years, the Queen was again pregnant and in this instance she gave birth to thirty girls, and the Queen raised them herself. When the boys grew up, they decided to search their mother and eventually found the woman in Kaniš who gave birth to thirty daughters at a time. The gods put other hearts into them, so both the mother and the children could not recognize each other. The youngest boy became aware of the situation when their mother tried to marry their daughters with them.

It is clear in this legend that the first family of these boys was a royal family. Their mother left the children in a basket on the river because of an extraordinary birth she gave, and the children were raised by the gods. Because the tablet was damaged, the end of the legend could not be learned.

\section{Osiris}

One of the stories about being thrown into the river in a basket took place also in Egyptian culture. The well-known of these set in Egypt is the legend of Osiris. ${ }^{33}$ According to the stories, Osiris taught people to enforce laws, to make agriculture, and people dignified and prized him very much. Thanks to the trust, assurance and loyalty of the people, Osiris could travel to any part of the country unarmed and unprotected. While Osiris was travelling, his wife İsis was also able to retain his throne. Seth secretly planned to seize the throne of Osiris and learned his body size and built a very beautifully inlaid crate/coffin. During a banquet, Seth offered that he would present this crate/coffin to the person who would fit exactly into it. Those who attended the banquet tried to enter in this crate in turn but none of them fit in it. Then Osiris entered in it, and his body could exactly fit it. Seeing Osiris entering the crate, Seth quickly closed the lid of the crate and poured molten lead on it. Then he left the ark on the Nile as he wanted the river take the ark away.

As soon as İsis noticed the disappearance her husband, she lost her senses and began searching him everywhere. She then learned that Osiris had been thrown him into the Nile River in a crate. She kept on seeking him and heard that the ark was on the shores of Byblos. A tree in Byblos has trapped the crate in itself. When the king of Byblos, Malcander saw the beauty of the tree, he commanded his men to make the columns of his palace of this tree.

While the tree was being cut, a beautiful fragrance began to spread around. This scent reached to Isis and she took the crate back to Egypt. Learning that the ark had been brought back to Egypt, Seth found it and

33 Plutarch Isis - Osiris, $13-18$. 
divided Osiris into fourteen pieces and distributed each piece in separate places. Isis went out in search of her husband's pieces and where she found the piece she built a temple in her husband's name there.

According to the legend that took place in Egypt, Osiris had already been a god worshipped by the people from the very beginning. In other words, his first part of life had already related to divinity. After he had been left in the coffin to the Nile River, he continued to be regarded as a god by his society.

\section{Attis}

One of the most widely known mythological stories belonging to ancient times is the mythos of Attis. This myth was conveyed in different ways by numerous antique writers ${ }^{34}$ without much modification of its main structure.

According to the information understood from the works of antique writers, this myth was as follows: When the hermaphrodite creature Agdistis' penis was cut off, a pomegranate tree emerged from the sperm that spreading on the ground. Seeing the beauty of the fruits of this pomegranate tree, Nana hid some of these pomegranates in her chest and became pregnant in an extraordinary way. Nana's father Sangarius, finding out that his daughter had become pregnant, imprisoned her with the intention of starving her to death with the thought of that his daughter had committed immorality. Nana was fed with food such as apple given by Cybele. ${ }^{35}$ After the child was born, he was abandoned on the edge of the Gallos River ${ }^{36}$ by Sangarius to leave him dead. The child may have been fed by animals so he was able to survive. When he grew up, he became a very handsome young man and became a favorite of the mother goddess.

34 We can learn about the mythos of Attis from the works of Arnobius, Catullus, Diodorus of Sicily, Julian, Ovidius and Pausanias. The most different narration of the story can be in the work of Diodorus of Sicily. According to his description, the child who was abandoned after he/she was born was not Attis but Cybele. The narrative of Diodorus of Sicily was as follows in summary: As soon as Cybele was born, he was abandoned by his mother on Mount Cybellus. Being abandoned on the mountain, the child was fed by leopards and miraculously survived. Attis and Cybele had a love affair, Attis was brought to the King's Palace and it was learned that Cybele was not a virgin. Cybele's father got angry, and Attis was killed. Diod III. $58-59$.

35 Arnobius V. 6, 7. The process up to the abandonment of Attis was described by Pausanias. According to his description, the demon called Agdistis appeared with the permission of Zeus. As the gods were afraid of this demon, they cut off his penis. The almond tree came out of the sperm that fell on the ground and Sangarius' daughter took these fruits and put them on her chest. That's why she got pregnant. Paus. VII. 17.9 - 11 .

36 Julian 262. In Catullus' narration, it is stated that he was in a tree bark on the sea. Catullus, LXIII. $1-5$. There is also different manner of telling that Attis was left to die but where he was abandoned is not stated. Arnob. V. 6.; Paus. VII. 17. 11. In addition, Ovid's narration never mentions that Attis was abandoned. Ovid's Fasti IV. 221 - 235. 
In the following of the story, When Attis was about to get married with someone else Cybele / Agdistis came to the wedding, ${ }^{37}$ Attis got angry with this situation and castrated himself (Arnobius V:7; Pausanias VII, 17.12). When he was on the verge of death, he was saved thanks to the goddess' begging to Zeus and his body was prevented to be decayed. Ater that, Attis was blessed by the people and considered both a semi-god, and a centaur. Hence a cult belonging to him was established.

In the legend of Attis narrated by many ancient writers it is accurate that his first family was the royal family, and a wealthy family. Since her mother fell pregnant in an unusual way, Attis was abandoned on the edge of the Gallos River, and he was fed by animals. Therefore, it can be considered that the second part of his life began in poverty. The next events gave Attis an opportunity to become one of the most important religious characters of the ancient Greek and Anatolian religions.

\section{Teukros}

As in the legend of Pyrrhus, there was a legend that was not left directly on the water directly. That was about the legend of Hesione. Although there are slight differences in the narrative of the ancient authors about this story, the general theme the story consistent with both in Apollodorus and Ovid's. ${ }^{38}$

According to Apollodorus, the legend began with the repair of the destroyed walls of Troy. The king of Troy, Laomedon, promised Apollo and Poseidon fee or offering in exchange for the repair of the walls. Although the gods restored the walls, the king did not keep his word. So Apollo spread deadly plague to the city, and Poseidon sent a sea monster. According to the oracles that the only way to get rid of the sea monster would be to present the king's sister Hesione to the sea monster. The king of Troy tied his sister to the cliff at the edge of the sea and left her there. Seeing the girl was abandoned

37 It was described differently by other authors. The wedding was not mentioned in Catullus' work, and the reason that he castrated himself was based simply on anger. Catul. LXIII 1 5. In Julian's work, Attis had a sexual relationship with Nymphe, and Cybele had seen this scene and acted against them. So Attis got angry and he castrated himself. Julian 265. In Ovid's version, there is a similar narrative to Julian's. According to Ovid's, Attis did not keep his promise to Cybele by having sexual intercourse with Sagaritis. Cybele got angry and, she cut down the tree on which Sagaritis' life depended. Getting mad because of Cybele's attitude, Attis threw himself to Mount Dindymon and he castrated himself there. Ovid's Fasti IV: 221 - 235. In the work of Diodorus, when the relationship between Cybellus (Cybele), the daughter of the king, and Attis, he was killed by the King. Diod. III: $58-59$.

38 Some little differences in the narrative of Ovid's existed. According to his story, all the straits of the country was covered by flood and all farm products were burned as he did not keep his promise. Moreover, Hesione was rescued thanks to Heracles and Telamon's collective effort. After that Hesione was given to Telamon to get married. Ovid's Metamorphoses XI. $194-220$. 
for the sea monster, Heracles asked the girl's older brother immortal horses in exchange for saving her from the sea monster. Laomedon accepted this offer, and Heracles saved her from the sea monster, but Laomedon again broke his promise. Therewith Heracles attacked against the city, but Telamon gained advantage over Heracles. Telamon who lost the fight, had gone to the city and started to build an alter on behalf of Heracles before Heracles arrived. Heracles was so pleased that he gave Hesione to Telamon to get married. As a result of their marriage Teukros came into the world. After many years, Teukros became one of the gallant soldiers in the Battle of Troy.

\section{Conclusion}

The stories of the children who would be in respectable positions such as hero, ruler or godlike being appear to be different from each other. However, when some points are examined in detail many similarities can be recognized. First of all, the common point of all the stories about the children's lives mentioned above comprise of two parts. Coming into the world as ordinary human beings is related to the first phase of their lives, and the second part of their lives contains the process of extraordinary survival stories and adulthood of these children after being left on water.

The most important object changing children's lives is water. The fact that water was regarded as the most important purifying object by ancient people is mentioned above. Thus, the child who is abandoned to water begins his new life as a pure and new individual.

When we examine the geographies of the abandonment places of the children, it can be claimed for Mediterranean civilizations that they have coherences in themselves. The setting of the legend of Sargon and Darab were in Mesopotamia; Moses and Osiris stories occurred in Egypt; the legends of Attis and Teukros took place in Anatolia; Telephos, Perseus and Pyrrhus legends were in the Greek mainland; the legend of Romulus and Fabius was in Italy; and Karna legend belonged to in Indian civilization. Therefore, the rivers where children were abandoned are the Euphrates, Nile, Tiber, Gallos and Ganges, which are considered to be the most important rivers of the regions. It is also seen that the children can also be abandoned on the Aegean Sea and an unknown river in Italy whose name is not mentioned in the Pyrrhus legend.

General view about such motives is that they appeared with intent to legitimize the status of religious people or rulers and to show that they had attained their position through divine powers. Because the popular opinion is that the children of poor families, who had no right to govern, took the control or became heroes or religious people by force. But when the first families of children abandoned on water are examined, it seems that it is not the case. 
Most of the protagonists of such stories in fact belong to upper class or relates to divinity. Darab, Attis, Telephos, Perseus, Romulus, Pyrrhus and Teukros have already been individuals belonging to the royal family. Moreover, it is learned from valuables left in baskets that Karna's first family is also a wealthy one. Osiris, on the other hand, is mentioned in Egyptian religious belief as a god with a human form.

In the legend of Fabius information about the status of his first family is not written by ancient authors. So it can be said that his first family may be an ordinary family. In The Legend of Similarly There is no information about the economic condition of the first family of Sargon, and also no mention about his father. The only thing known about his first life is that his mother is a priestess. We can interpret the fact of not being mentioned about his father in the story as, he is absolutely mentioned if he is an important person. Therefore, it can be judged from this, it is possible that the first family of Sargon is a poor and is not a member of upper class. On the other hand, as it is stated in the Old Testament Moses has an ordinary poor Levian family.

There is a balanced distribution in the case of the families' statues who find and raise the children abandoned on water. Sargon, Darab, Karna and Pyrrhus are found by poor families. Attis and Romulus are rescued and fed by animals so that they can survive. Moses, Telephos and Perseus are found by wealthy and ruling families and are raised by adoption. At this point, a rapid change in Pyrrhus's destiny is observed. He is first rescued by a poor family and then adopted and raised by the king of Illyria. Being recovered by animals, Romulus was raised by a shepherd family. Lastly, it is not remarked that by whom Attis is raised after being abandoned and found by the animals.

Among the reasons for abandonment of children, the secret relationship with god comes to the fore. In the legends of Telephos, Perseus, Romulus, Fabius, children are abandoned depending on this reason. It is noted that Sargon, Karna, and Attis are all left after their secret birth. So their father is a mortal man instead of a god. In addition to these, Moses is abandoned because of general massacre, Darab is left due to his mother's fear of losing the throne, and in order to escape from his father's enemies Pyrrhus is left on water and finally Teukros was abandoned as a result of the prophecy and desire to present an offer to a god. In the majority of the stories mentioned above, the one who causes the children to be abandoned is the king. In other words, the abandonment of children on water is directly related with the order of the king of the country. In fact, when we consider that the children's first families are wealthy and ruling families, it can be said that the children are abandoned by the command of their family members. 
Another common point of these stories is that especially after they are rescued from water and when these children grow up they become important personages leading the society. Sargon, Darab, Karna, Telephos, Romulus, Fabius and Pyrrhus become kings or rulers. Moses, Osiris and Attis appear as religious characters, while Perseus and Teukros are seen as mythic heroes with superhuman powers.

When we pay attention especially to the first families of the most of children abandoned, it is seen that they belong to the royal family (Darab, Attis, Telephos, Perseus, Ronulus, Pyrrhus, Teukros) or the upper class (Karna, may be Fabius), and therefore they are in fact the heirs who have the right to govern the country. So we can deduce that these myths are not intended to legitimize themselves. In this case, the question arises why the rulers are given a role in such myths, especially in ancient Greek and Roman societies, if the is not to legitimize themselves.

The answer of this question is not known for certain. In the legends of Sargon and Moses, which we can regard as the earliest examples of these kind, the first family is poor, meaning that they cannot be claimant in both political and religious issues. The prominence of people who should not have a say in the administration or religious life brings the question of legitimacy in mind. To overcome this problem, the myth of abandonment of water may have played an important role in legitimizing these individuals. The subsequent rulers in different geographies may have wanted to be involved in such myths in order not to lag behind or to strengthen their legitimacy, even though they knew that they would have a say in the administration in the future. Taking these facts into consideration, it can be said that the rulers of the ancient Greek and Roman periods were already the legal heirs of the royal family, and that they had the purpose of legitimizing themselves indirectly through such mythological legends.

Although people living in ancient times rarely witnessed the abandonment of male child in real life, they believed such legends comprising the theme of that the royal families abandoned their boys. Because it is conceivable that these societies could have wanted to regard their rulers, clergy and heroes as extraordinary and superhuman beings receiving the support of the gods. Therefore, the legends of abandonment in an ark on water can be considered as common myths that they have been accepted to in many societies, regardless of the need for legitimacy or not. It can be suggested the earliest examples of the motif of exposure to water can be used in the legitimation method, but it is not needed in the examples in the Classical period according to this information. 


\section{BIBLIOGRAPHY}

\section{Ancient Sources}

Apol. Apollodorus. The Library. Translate: James George Frazer. London - New York, 1921.

Arnob. Arnobius. The Seven Books of Arnobius Adversus Gentes. Translate: Arch ${ }^{\mathrm{d}}$ Hamilton Bryce - Hugh Campbell, Edinburg 1871.

Catul. Gaius Valerius Catullus. The Poems of Gaius Valerius Catullus. Translate: Charles Stuttaford, London: Chiswick Press, 1912.

Diod. Diodorus. Diodorus of Sicily. In Twelve Volumes II, English Translation by: C. H. Oldfather, London - Massachusetts: Harward University Press, 1967.

Julian the Apostate. Julian the Emperor. Containing Gregory Nazianzen's Two Invectives and Libanius Monody London: George Bell and Sons, 1988.

Livius. Titus Livius, The History of Rome. Translate: Canon Roberts, London: J. M. Dent \& Sons, 1905.

Mahabbarata. The Mahabbarata of Krishna-Dwaipayana Vyasa. Translated into English Prose from the Original Sanskrit Text by Kisari Mohan Ganguli, XII. 2003.

Exodus. Old Testament. The King James Version of the Holy Bible, 2004.

Fasti. Publius Ovidius Naso, Ovid's Fasti. Translate: James George Frazer, London Massachusetts: Harward University Press, 1959.

Meta. Publius Ovidius Naso, Ovid's Metamorphoses. Translate: A. S. Kline, 2000.

Paus. Pausanias, Description of Greece. Translete: W. H. S. Jones, London - New York: 1918.

Plut. Fab. Plutarch, "Fabius". Plutarch's Lives. with an English Translation by: Bernadotte Perrin, Great Britain: The Windmill Press, 1932: pp. 11 - 197.

Plut. Isis. Plutarch, "Isis and Osiris", Plutarch Moralia. vol: V, with an English Translation by: Frank Cole Babbitt, London: Harward University Press, 2003.

Plut. Pyrr. Plutarch, "Pyrrhus", Plutarch's Lives. Translate: Bernadotte Perrin, London: Harward University Press, 1932: pp. 1 - 47.

Plut. Romul. Plutarch, "Romulus", Plutarch's Lives. Translate: Bernadotte Perrin, London - New York: 1914: pp. $89-187$.

Shah. The Shahname of Firdausi. vol. V, Done into English by Arthur George, M. A. and Edmond Warner, London: Trubner's Oriental Series.

Strab. Strabon, Geographica. Translate: Adnan Pekman, İstanbul: Arkeoloji ve Sanat Yayınları, 2009.

\section{Modern Sources}

Brulé, Pierre. "L'exposition Des Enfants En Grèce Antique: Une Form D'infanticide." Enfances \& Psy 3 (2009): pp. 19 - 28. 
Eliade, Mircea. Mitlerin Özellikleri. Translate: Sema Rifat, İstanbul: Om Yayınevi, 2001.

Eliade, Mircea. Dinler Tarihine Giriş. Translate: Lale Arslan, İstanbul: Kabalcı Yayınevi, 2003.

Eliade, Mircea. Demirciler ve Simyacılar. Translate: Mehmet Emin Özcan, İstanbul: Kabalcı Yayınevi, 2003.

Eliade, Mircea. Rites and Symbols of Initation the Mysteries of Birth and Rebirth. New York: Harper Colophon Books, 1958.

Erdemir, Hatice Palaz and Erdemir, Halil. "Antikçağ' da Çocuk Olmak: Ölmek ya da Ölmemek." The Symposium of Violence against Women and Children Proceedings Book, (2012): 643 - 659.

Frazer, James George. The Golden Bough I. A Study Comparative Religion. New York and London: Macmillan and Co, 1894.

Frazer, James George. The Golden Bough II. A Study Comparative Religion. New York and London: Macmillan and Co, 1894.

Frazer, James George. Man, God and Immortality Thoughts on Human Progress. London: Macmillen and Co, 1927.

Freud, Sigmund. Moses and Monotheism. Translated from the German By Katherine Jones, Hertfordshire: Hogarth Press and the Institute of Psycho - Analysis, 1939.

Harris, W. V. "Child-Exposure in the Roman Empire.” The Journal of Roman Studies, 84, (1994): $1-22$.

Hook, La Rue van. "The Exposure of Infants at Athens." Transactions and Proceedings of the American Philological Association, 51, (1920): 134-145.

Lévy-Bruhl, Lucien. Illkel Toplumlarda Mistik Deneyim ve Simgeler. Translate: Oğuz Adanır, İstanbul: Doğu Batı Yayınları, 2006.

Pedrucci, Giulia. "Breastfeeding Animals and Other Wild "Nurses" in Greek and Roman Mythology." Gerión, 34, (2016): 307 - 323.

Otten, Heinrich. Eine Althethitische Erzählung um die Stadt Zalpa. Otto Harrassowitz Wiesbaden: Studien zu den Boğazköy - Texten, 1973.

Konijnenberg, Marlies. Infanticide and the Social Status of Children As Reflected in Child Burials, Unpublished BA Thesis, 2014.

Philips, F. Carter. "Greek Myths and the Uses of Myths." The Classical Journal. LXXIV/2 (1979): $155-166$.

Rank, Otto. The Myth of the Birth of the Hero A Psychological Interpretation of Mythology. New York: The Journal of Nervous and Mental Disease Publishing Company, 1914.

Redford, Donald B. "The Literary Motif of the Exposed Child (Cf. Ex. ii 1 - 10)." Numen XIV/3 (1967): $209-228$. 
Speiser, E. A. "Akkadian Myths and Epics from Mesopotamia." The Ancient Near East. I - An Anthology Of Texts And Pictures. ed. J. B. Pritchard (Princeton: Princeton University Press, 1968): 31 - 86.

Winter, Irene J. "Touched by the Gods: Visual Evidence fort he Divine Status of Rulers in the Ancient Near East." Religion and Power Divine Kingship in the Ancient World and Beyond, ed. Nicole Brisch, Chicago: The Orieantal Institute, 2008: 75 - 102.

Winternitz, Moritz. Hint Destanları Rāmāyana, Mahābhārata, Harivamşa, Translate: Korhan Kaya, Ankara: İmge Kitabevi, 2016. 
AN EXAMPLE OF MEANINGLESS LEGITIMIZATION...

\begin{tabular}{|c|c|c|c|c|c|c|c|c|c|c|c|c|c|}
\hline 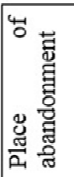 & 莺 & & & & 竎 & & 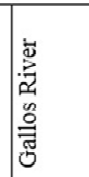 & 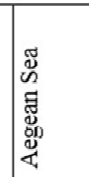 & 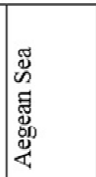 & 莺 & 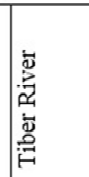 & 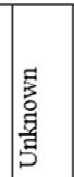 & 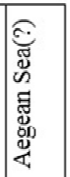 \\
\hline 衰 & 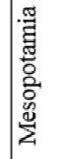 & 䓛 & 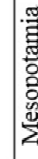 & & 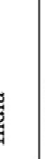 & 䓵 & $\begin{array}{l}\frac{\pi}{3} \\
\frac{3}{3} \\
\frac{\pi}{4}\end{array}$ & 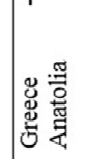 & 芯 & 䮃 & 密 & $\begin{array}{l}\text { 离 } \\
\text { 号 }\end{array}$ & 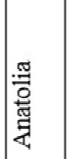 \\
\hline $\begin{array}{l}\text { 号 } \\
\text { 总 } \\
\text { in }\end{array}$ & 驾 & 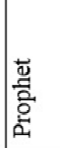 & . & & 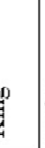 & 惫 & 密 & 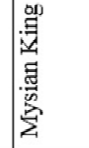 & 䇋 & 然 & $\mid$\begin{tabular}{|l}
$\vec{a}$ \\
$\vec{\mu}$
\end{tabular} & 架 & 总 \\
\hline 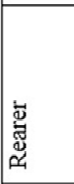 & 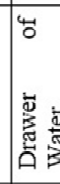 & 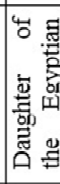 & ? & & : & & 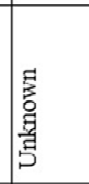 & 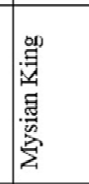 & 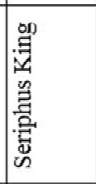 & 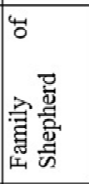 & 春 & 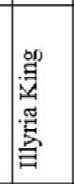 & 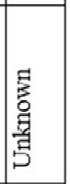 \\
\hline 离 & 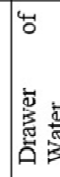 & 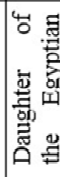 & 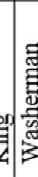 & & 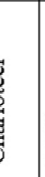 & 㤩 & 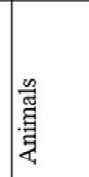 & 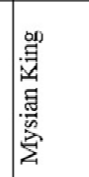 & 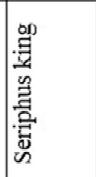 & 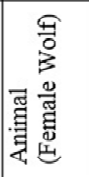 & 豆 & 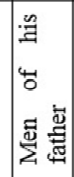 & 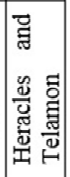 \\
\hline 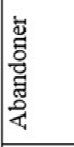 & 产 & 离 & 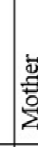 & & 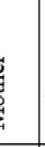 & 㔄 & 离 & 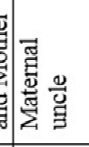 & 嵒 & 照 & 夆 & 吾 & 串 \\
\hline 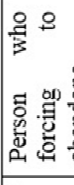 & 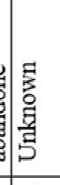 & $\begin{array}{l}\text { 总 } \\
\text { 鄫 }\end{array}$ & 量 & & 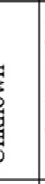 & 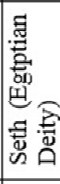 & 离 & 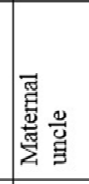 & 毠 & 竞 & $\begin{array}{l}\text { 胥 } \\
\text { 鄫 } \\
\end{array}$ & 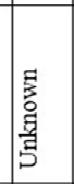 & 串 \\
\hline 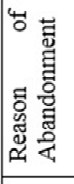 & 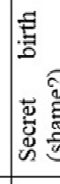 & 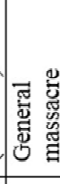 & 1 & & & $\begin{array}{l}\tilde{g} \\
\tilde{m}\end{array}$ & 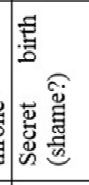 & 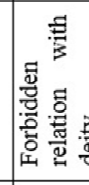 & 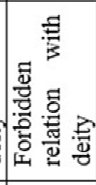 & 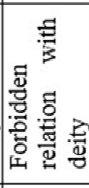 & 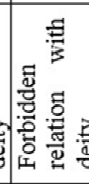 & 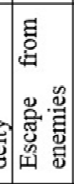 & 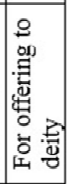 \\
\hline 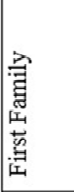 & 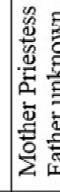 & 产 & . & & 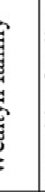 & 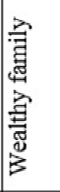 & 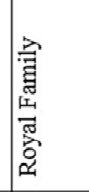 & 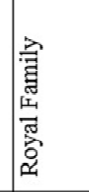 & 产 & 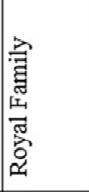 & 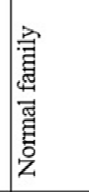 & 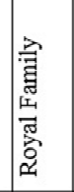 & 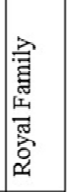 \\
\hline & $\begin{array}{l}\text { 总 } \\
\text { 昜 }\end{array}$ & 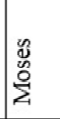 & & & & 营 & 等 & 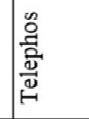 & 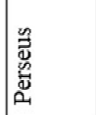 & 魚 & $\mid \begin{array}{l}\text { 急 } \\
\text { 离 }\end{array}$ & 善 & 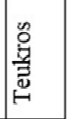 \\
\hline
\end{tabular}

